\title{
Antidiabetic, Antibacterial and Antioxidant Potential of Bioactive Peptides Extracted from the Germinated Seeds of Poncirus trifoliata
}

\author{
Tahir Mehmood ${ }^{1,2 *}$, Rana Waqar Ahmad ${ }^{2}$, Fareeha Nadeem ${ }^{1}$, Shagufta Saeed ${ }^{1}$, Huma Mujhaid ${ }^{1}$ and Sadaf Imran $^{3}$ \\ ${ }^{1}$ Institute of Biochemistry and Biotechnology, University of Veterinary and Animal Sciences-UVAS, Lahore 54000, Pakistan \\ ${ }^{2}$ Institute of Chemistry, University of Sargodha, Sargodha 40100, Pakistan \\ ${ }^{3}$ Department of Veterinary Surgery and Pet science, University of Veterinary and Animal Sciences-UVAS, Lahore 54000, \\ Pakistan
}

*For correspondence: tahir.mehmoodbiochem@uvas.edu.pk

Received 08 May 2021; Accepted 27 May 2021; Published 10 July 2021

\begin{abstract}
The seeds proteins are converted into the peptides during the germination through peptidases. These bioactive peptides are fractionated through the enzymes. The bioactive peptides are reported with the number of therapeutic effects like antioxidant, antibacterial, antidiabetic, anti-cancerous and antihypertensive etc. Synthetic drugs have number of adverse effects along with the therapeutic effects, but natural sources are safer and free from this problem. In the present research, Poncirus trifoliata seedling peptides extracts were used to determine antibacterial, antioxidant and anti-diabetic activities. The peptides extract showed substantial growth of inhibition against pathogenic strains including Escherichia coli, Staphylococcus aureus and Bacillus subtilis having the superior effect as compared to amoxicillin antibiotic as a standard drug. The $\mathrm{IC}_{50}$ value of $P$. trifoliata seeds peptides extract was $32.91 \mu \mathrm{g} \mathrm{mL}^{-1}$ as compared with standard $\left(\mathrm{IC}_{50}\right)$ value $25.52 \mu \mathrm{g} \mathrm{mL} \mathrm{m}^{-1}$ of ascorbic acid showed good potential as antioxidant activity. The extracted germinated seeds peptides showed considerable antidiabetic activity in controlling the blood glucose level of alloxan induced diabetic rabbits to compare with standard drugs like glibenclamide. Thus, this study confirmed the antibacterial, antioxidant and antidiabetic effects of $P$. trifoliata seeds peptides is significantly higher as compared to pure drugs. Therefore, further complete separation and detailed investigation study is needed to isolate target peptides and revealed mechanism of action of bioactive peptides and formulation as a drug to replace the synthetics drugs with safe one. (C) 2021 Friends Science Publishers
\end{abstract}

Keywords: Alloxan induced diabetes; Antibacterial activity; Antioxidant; Bioactive peptides; Seedling; Poncirus trifoliata

\section{Introduction}

Proteins are vital ingredients present in foods and give a widespread variety of biological, nutritional and functional properties (Mazorra-Manzano et al. 2018). Peptides and bioactive peptides are differentiated on the bases of the therapeutic or regulatory effect. The peptides that have therapeutic and regulatory effects in the body are classified as the bioactive peptides. Bioactive peptides are defined as specific fragments of protein having an optimistic effect on function and condition of body (Walther and Sieber 2011; Kaur et al. 2020). These are biologically active organic substances having length of 2 to 10 amino acids joined together by peptide or amide bond, which is covalent in nature while proteins are composed of polypeptides having larger molecular weight (Moller et al. 2008; Fields et al. 2009). The sequence and composition of amino acids regulates the peptide activity when they are released after proteolytic action on proteins (Naveed et al. 2020). Proteins and their peptides play a significant role in metabolism of living creatures and subsequently in human well-being. They show drug like and hormonal actions and further classification of these peptides based on their activities as antithrombotic, opioid, antimicrobial, antioxidative, anticancer, antihypertensive, and immunomodulatory agents (Fields et al. 2009). Now, in 'BIOPEP-UMB' database 4031 bioactive peptides have been reported (Minkiewicz et al. 2019).

Natural sources like plants, microbes, animals and their releasing products encompass innumerable proteins in them. In this era, Global scenario is moving towards utilization of renewable and natural resources material into value added commodities (Nadeem et al. 2019). Poncirus trifoliata belongs to the family of Rutaceae. Its native range is Central and Northern China. It is well-branched, deciduous shrub or small tree which typically grows 8-15 (less frequently to 20') tall. Three-lobed (trifoliate as per the species name) leaves emerge yellowish-green in spring, turn glossy dark green in summer and fade to yellow in autumn (Tundis et al. 2016; Hall et al. 2018). Now in this work,

To cite this paper: Mehmood T, RW Ahmad, F Nadeem, S Saeed, H Mujhaid, S Imran (2021). Antidiabetic, antibacterial and antioxidant potential of bioactive peptides extracted from the germinated seeds of Poncirus trifoliata. Intl J Agric Biol 26:303-308 
seeds of $P$. trifoliate were selected because at germinating stages genome expresses and produces a maximum amount of protein/peptides. Research was planned to access the pharmacological potential of these peptides isolated from germinating seeds.

\section{Materials and Methods}

\section{Chemicals and collection of seeds}

In this work, all chemicals were used as an analytical grade. The seeds of ripened fruit $P$. trifoliate were collected from District Sargodha (also known as the Kino capital of the World) Pakistan as shown in (Fig. 1). All seeds were rinsed with the $0.1 \mathrm{M}$ sodium hypochlorite for $5 \mathrm{~min}$ and then washed with distilled water to remove the debris and dust particles.

\section{Seed's germination}

Poncirus trifoliata seeds take a long time for germination so for reduction of their germination time we removed seeds coating. Then soaked them in water for 5 to $6 \mathrm{~h}$ and then transferred them on the sterilized paper. $P$. trifoliata seeds were taken 10 to 15 days for growth at $25-30^{\circ} \mathrm{C}$.

\section{Extract preparation}

Poncirus trifoliata seedling was started on the $10^{\text {th }}$ day when the seedling became prominent. On the $12^{\text {th }}$ day all seeds were collected and referred to the grinding using chilled pestle and mortar. Peptides were extracted by using tris $\mathrm{HCl}$ 0.1 Molar and 0.5 molar $\mathrm{NaCl}(\mathrm{pH} \mathrm{8})$ for $2 \mathrm{~h}$ and then supernatant was collected. The seeds by weight and volume of molar solution were used by 1:4 ratios. Then this supernatant was subjected to $12000 \mathrm{rpm}$ for $20 \mathrm{~min}$ at $4^{\circ} \mathrm{C}$ and again the supernatant was collected for further processing (Costa et al. 2001).

\section{Total Protein/Peptides content determination}

To check the protein/peptides content Bovine serum albumin (BSA) was used as a standard by spectrophotometric method (Ali et al. 2016).

\section{Antibacterial activity}

The disc diffusion method was used to check the antibacterial activity against the pathogenic strains including Escherichia coli, Staphylococcus aureus and Bacillus subtilis (Khan et al. 2017).

\section{Microbial growth}

The pure culture of microbial strains E. coli, S. aureus and B. subtilis were taken from Department of Food
University of Sargodha, Pakistan. The fresh colonies were prepared by using nutrient Agar medium. The composition of NA medium was as follow (g/100): peptone: 0.5 , Yeast extract: $0.3, \mathrm{NaCl}$ : 0.5 and Agar: 1.5. It was autoclaved at $120^{\circ} \mathrm{C}$ for sterilization purpose for 30 min (Mehmood et al. 2019). Stock was preserved at $4^{\circ} \mathrm{C}$ on slants of nutrient agar medium (Muruganantham et al. 2016).

\section{Sample preparation}

A stock solution has peptides concentration of $12.8 \mathrm{mg} \mathrm{mL}$ ${ }^{1}$. The four types of dilution solution were used to evaluate the antibacterial activity. The original Conc used and twofolds diluted with distilled water $\left(6.4 \mathrm{mg} \mathrm{mL}^{-1}\right)$. Three-folds $\left(4.266 \mathrm{mg} \mathrm{mL}^{-1}\right)$ of the diluted solution of peptides extract was prepared adding distilled water and also used four-folds (3.2 $\mathrm{mg} \mathrm{mL}^{-1}$ ) of diluted solution of peptides extract was prepared by adding distilled water and the standard solution of the amoxicillin $\left(10 \mathrm{mg} \mathrm{mL}^{-1}\right)$.

\section{Disc diffusion method}

The antibacterial activity of peptides was checked by disc diffusion method. Whatman filter paper No.1 having $6 \mathrm{~mm}$ in diameter was used to form the paper discs. These paper discs were impregnated with the standard drug amoxicillin $\left(10 \mathrm{mg} \mathrm{mL}^{-1}, 100 \mu \mathrm{g} / \mathrm{disc}\right.$ used) and the sample dilutions to be tested. These impregnated discs were placed on the culture media to compare the antibacterial activity. These plates were incubated at $37^{\circ} \mathrm{C}$ for $48 \mathrm{~h}$. The diameter of zone of growth inhibition around the impregnated discs was measured to check the antibacterial activity of the extract in relation to the standard drug amoxicillin (Salman et al. 2016).

\section{Antioxidant Assay}

Antioxidant activity was done according to the methodology adopted by Brand-Williams et al. (1995) with alterations. In this method, the stable compound $\alpha, \alpha$-biphenyl- $\beta$ picrylhydrazyl (DPPH; $\mathrm{C}_{18} \mathrm{H}_{12} \mathrm{~N}_{5} \mathrm{O}_{6}, M=394.33$ ) which is simply known as the 2,2'- diphenylpicryl-1-hydrazyl DPPH was used. This assay depends upon the scavenging activity of the antioxidant which is shown towards the DPPH. The reduction of the odd electrons of hydrazine nitrogen occurred by receiving the hydrogen from the antioxidants. The activity of radical scavenger was uttered in terms of the volume of antioxidants essential to reduce the initial absorbance of DPPH by $50 \%$ $\left(\mathrm{IC}_{50}\right)$. Different concentrations of peptides extract i.e., 8, $16,25.6,32,42.6,64,106,128\left(\mu \mathrm{g} \mathrm{mL}^{-1}\right)$ were prepared and the $5 \mathrm{~mL}$ reagent of DPPH $\left(4 \mathrm{mg} 100 \mathrm{~mL}^{-1}\right)$ was added in each extract solution. The test tubes were covered by the aluminum foil to avoid the effect of light. The prepared solution will reagent vigorously and incubate for $30 \mathrm{~min}$ at 
room temperature. The absorbance was taken at $517 \mathrm{~nm}$ and methanol was taken as the blank. Ascorbic acid was taken as the positive control. The equation given below was used to calculate the percentage free radical scavenging activity.

\%Antiradical activity $=\frac{\text { Control absorbance }- \text { Sample absorbance }}{\text { Control absorbance }} \times 100$

\section{Antidiabetic assay}

Male and female rabbits (Oryctolagus cuniculus) having weight of 1 to $1.2 \mathrm{~kg}$ respectively were obtained from University of Veterinary and Animal Sciences Lahore, Pakistan. The animals were saved in huge commodious cages in the animal stock of Department of Pharmacy, University of Sargodha, and were retained according to "Principals of Laboratory Animal Care" (NIH publication 85-23, reviewed in 1985) (Health 1985). Rabbitswere retained under standard conditions of temperature $(23 \pm$ $\left.12^{\circ} \mathrm{C}\right)$ and humidity $(55 \pm 15 \%)$ with $12 \mathrm{~h}$ light and dark cycle (Iranloye et al. 2011). Experimental rabbits facilitated the food and abundant water.

\section{Sample preparation}

Rabbits (Oryctolagus cuniculus) were divided into three groups. Group 1was served with $20 \mathrm{~mL}$ solution of $2 \%$ gum tragacanth which serves as a control group. Group 2 was alloxan induced diabetic (Type 1) group. To induce diabetes animals were fastened overnight and injected $150 \mathrm{mg} \mathrm{kg}^{-1}$ dose of the alloxan through the ear vein with the help of 25gauge catheter for easiness. Induction of diabetes was confirmed after the $72 \mathrm{~h}$ by testing the blood glucose level. The rabbits which have shown blood glucose in the range of 250-300 mg dL ${ }^{-1}$ were considered as the diabetic and were employed to check the anti-diabetic activity of the extract (Tafesse et al. 2017). Group 3was also the diabetic group of rabbits to which the standard drug glibenclamide $600 \mu \mathrm{g} \mathrm{kg}^{-}$ ${ }^{1}$ was given. The glucose level of all groups of rabbits was measured on day 0,15 and 30 .

\section{Statistical analysis}

All the trial was performed in triplicates. Means and standard errors of means (Mean \pm S.E.) were calculated for each trail and used to draw the tables and Figures where pertinent (Ayatollahi et al. 2019).

\section{Results}

\section{Protein/peptides estimation}

Bradford assay was used to check protein/peptide contents of $P$. trifoliata germinating seeds. Results declared that the concentration of the protein/peptides in germinating seeds extract solution is $12.8 \mathrm{mg} \mathrm{mL}^{-1}$.

\section{Antibacterial activity}

A stock solution has peptides concentration of $12.8 \mathrm{mg}$ $\mathrm{mL}^{-1}$. The four types of dilution were used to evaluate the antibacterial activity. Take $1 \mathrm{~mL}$ of stock solution of peptides extract was added in test tube and make volume up to $10 \mathrm{~mL}\left(1.28 \mathrm{mg} \mathrm{mL}^{-1}\right)$. Then prepare two-folds $(0.64 \mathrm{mg}$ $\left.\mathrm{mL}^{-1}\right)$ of diluted solution of peptides extract by $(1.28 / 2 \mathrm{mg}$ $\left.\mathrm{mL}^{-1}\right)$. Three-folds $\left(0.4266 \mathrm{mg} \mathrm{mL}^{-1}\right)$ of the diluted solution of peptides extract was prepared by $1.28 / 3 \mathrm{mg} \mathrm{mL}^{-1}$ and four folds $\left(0.32 \mathrm{mg} \mathrm{mL}^{-1}\right)$ of diluted solution of peptides extract was prepared by $1.28 / 4 \mathrm{mg} \mathrm{mL}^{-1}$ and also dissolve the standard solution of the amoxicillin $\left(1 \mathrm{mg} \mathrm{mL}^{-1}\right) \mathrm{drug}$.

\section{Antioxidant potential}

The antioxidant activity of $P$. trifoliata seeds peptides/protein extract was evaluated by DPPH assay. Results showed when concentration of peptides extract increases absorbance of peptides extract decreases it shows that when peptides extract concentration increases more peptides bind with free radicals and color of DPPH reagent decreases it indicates more free radical scavenging activity (Table 1, 2). DPPH assay aims for measuring hydrogen atom or electron giving capacity of the extracts to the DPPH stable radical formed in resultant solution. Results were presented by inhibitory concentration $\left(\mathrm{IC}_{50}\right)$ defined as those concentration where sample caused $50 \%$ decreased as compared to initial concentration of $\mathrm{DPPH} \bullet, \mathrm{O}_{2}^{\bullet-}, \mathrm{HO} \bullet$ and ABTS • and $\left(\mathrm{IC}_{50}\right)$ was calculated by linear relationship between sample concentration and free radical scavenging activity in (Fig. 2). ( $\mathrm{IC}_{50}$ ) value of $P$. trifoliata seeds peptides extract was $32.91 \mu \mathrm{g} \mathrm{mL}^{-1}$ when compared with standard ( $\mathrm{IC}_{50}$ ) value $25.51 \mu \mathrm{g} / \mathrm{mL}$ of ascorbic acid. Results showed the good antioxidant activity of peptides extracted from $P$. trifoliata seeds which is nearly equal to the ascorbic acid as a standard free radical scavenging activity.

\section{Antidiabetic potential}

Antidiabetic activity of $P$. trifoliata seeds peptides extract was assessed by alloxan induced method. Experiment was performed on three groups. Results presented in (Fig. 3) in which alloxan induced diabetic rat of group 2 were treated with $51.2 \mathrm{mg} \mathrm{kg}^{-1}$ dose of peptides extract. The blood glucose level was recorded on day 0,15 and 30. Results of group 2 came near with group 3 blood glucose level which was diabetic rabbits and treated with standard drugs like glibenclamide $600 \mu \mathrm{g} \mathrm{kg}^{-1}$. The $P$. trifoliata seeds peptides extract showed convincing antidiabetic activity in controlling the glucose level of blood. Naturally sources can play a significant character in preparing the cells for insulin and activates the $\beta$-cells of pancreas to raise the production of insulin. The considerable antidiabetic activity of $P$. trifoliate germinating seeds peptides extract provides us with a natural remedy against the diabetes mellitus. 
Mehmood et al. / Intl J Agric Biol, Vol 26, No 2, 2021

Table 1: Zone of inhibition of $P$. trifoliate seeds peptides extract in comparison of antibiotic amoxicillin used as a standard

\begin{tabular}{lllll}
\hline S. No. & Antibacterial solutions & Escherichia coli & Staphylococcus aureus & Bacillus subtilis \\
\cline { 3 - 4 } & & \multicolumn{3}{c}{ Growth inhibition Zone in mm } \\
\hline 1 & Amoxicillin $\left(1 \mathrm{mg} \mathrm{mL}^{-1}\right)$ & 17 & 15 \\
2 & One-fold peptides extract $\left(1.28 \mathrm{mg} \mathrm{mL}^{-1}\right)$ & 18 & 15 & 16 \\
3 & Two-fold peptides extract $\left(0.64 \mathrm{mg} \mathrm{mL}^{-1}\right)$ & 12 & 10 & 12 \\
4 & Three-fold peptides extract $\left(0.4266 \mathrm{mg} \mathrm{mL}^{-1}\right)$ & 5 & 4 & 5 \\
\hline
\end{tabular}

Table 2: Percentage inhibition activity of $P$. trifoliata seeds peptides extract

\begin{tabular}{llll}
\hline S. No. & Concentration of peptide extract $\left(\mu \mathrm{g} \mathrm{mL}^{-1}\right)$ & Absorbance of extract $(517 \mathrm{~nm})$ & Inhibition \% Ctrl-abs/ctrl $\times 100$ \\
\hline 1 & 8 & 0.1498 & 42.4228 \\
2 & 16 & 0.1424 & 45.2728 \\
3 & 25.6 & 0.1354 & 47.9631 \\
4 & 32 & 0.1302 & 49.9615 \\
5 & 42.6 & 0.1226 & 52.8823 \\
6 & 64 & 0.1052 & 59.5695 \\
7 & 106 & 0.0791 & 69.6003 \\
8 & 128 & 0.0565 & 78.2859 \\
\hline
\end{tabular}

Ctrl $=$ absorbance of control, Control value $=0.2602$, Abs $=$ absorbance of extracts

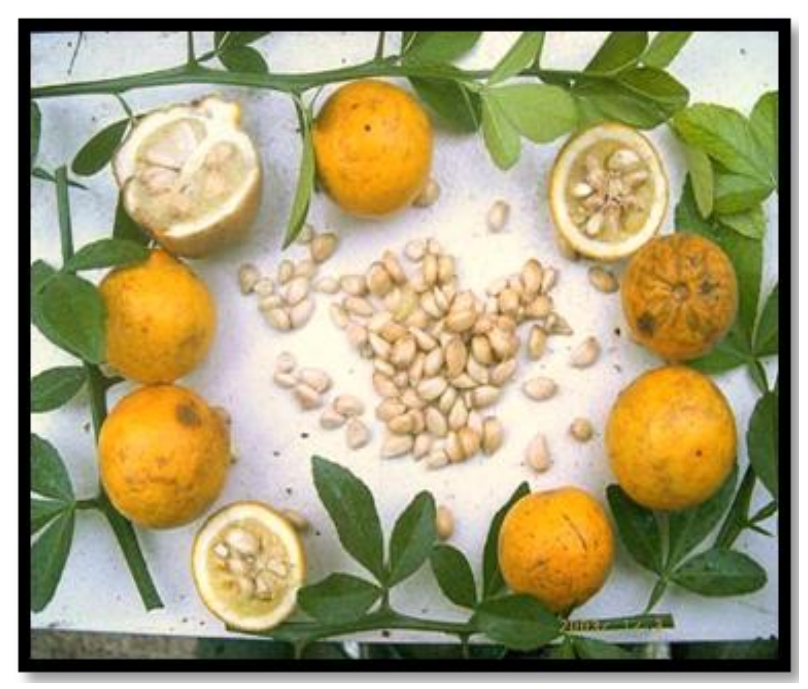

Fig. 1: Poncirus trifoliata ripened fruit and seeds

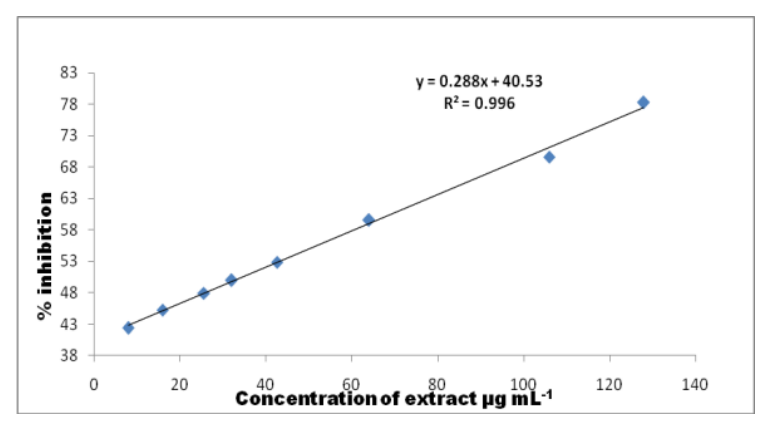

Fig. 2: Percentage inhibition of free radicals by different concentration of $P$. trifoliata seeds peptides extract

\section{Discussion}

Based on previous literature reported by Kumar et al. (2016) evaluation of different parameters was done on non-

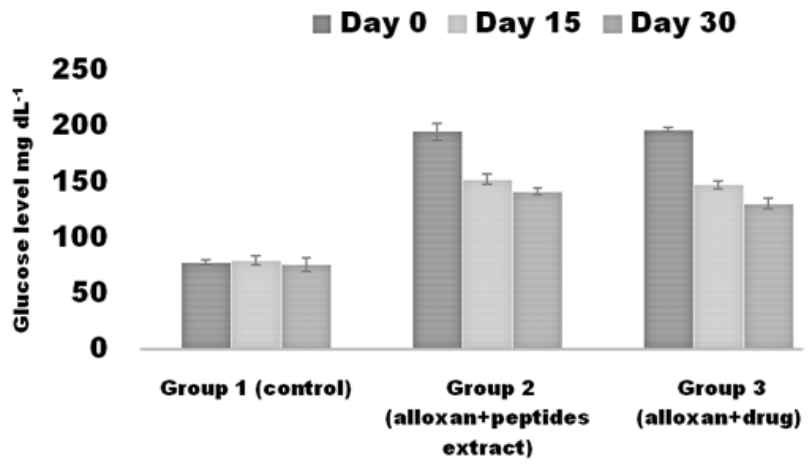

Fig. 3: Antidiabetic activity of $P$. trifoliate seeds peptides extract

germinating and germinating seeds of Cucurbita maxima. Results revealed that non-germinating seeds contained high amounts of reducing, non-reducing sugars, lipids and calorific value while germinating seeds showed high amounts of proteins, DNA and phytochemicals. Germination of seed is a critical phase in growth of plants and can be recognized as a basis for productivity of plants. It initiates with water $\left(\mathrm{H}_{2} \mathrm{O}\right)$ imbibition, food reserve mobilization, significance radicle protrusion and synthesis of protein. To maintain a worthy seedling growth, seed stocks a food reserve mainly as proteins, carbohydrates and lipids. Proteins and lubricant bodies are core reserves in oilseed which embody as a source of energy in the form of nitrogen and carbon throughout seedling formation (Abuin $e t$ al. 2002). After the genome starts expressing stored proteins undergo hydrolysis and releases free amino acids, for protein synthesis in embryo and endosperm for proceeding the process of germination (Ali and Elozeiri 2017).

Our results show similarity with already reported data in which hydrolysis of casein was done by cysteine proteases from Jacaratiaco rumbensis. After 2 h hydrolysis, the release product was energetic against bacteria like $B$. subtilis, Pseudomonas aeruginosa, Enterococcus faecalis, 
Klebsiella pneumonia, E. coli and S. aureus (Arruda et al. 2012). Mohanty et al. (2016) reported whey protein release peptides having antibacterial activity against $E$. coli, Clostridium sp., B. stearothermophilus, Vibrio cholerae, Legionella pneumophila, B. subtilis, Haemophilus influenza and Streptococcus mutans. Bromelain was capable of liberating antibacterial peptides from Meuschenia species protein of leather jackets. This release of hydrolysate showed antimicrobial against $B$. cereus and $S$. aureus (Salampessy et al. 2010). The bacteria showed resistance against artificial antibacterial agents so their usage is limited to preserve in foodstuff. Antibacterial peptides obtained from natural sources have a great potential to substitute artificial antibacterial agents owing to their less toxic nature and fewer ecological risk. Antibacterial peptides produced by food proteins hydrolysis catalyzed by proteases present in plants have grown significantly.

Our findings show similarity with Grancieri et al. (2019) who reported that Salvia hispanica L. (chia seed) are a good source of antioxidants. It inhibits $\mathrm{NF}_{-\mathrm{K}} \mathrm{B}$ transcription factor activation in vitro along with reducing carcinogenic and inflammatory processes and provides protection against the nitrogen and reactive oxygen species (ROS). Kooti and Daraei (2017) reported celery (Apium graveolens) seeds, leaves and essential oils have good antioxidant properties because of presence of these compounds like ferulic acid, luteolin, caffeic acid, tannin, $p$ coumaric acid, apigenin, kaempferol and saponin while diverse complexes of this plant with different concentration having different therapeutic effects. It has been reported by Derakhshan et al. (2018) that after experimental study on pomegranate seeds, juice, and peels it was observed that all parts of pomegranate showed good antioxidant activity but more activity was obtained by pomegranate peels. Medical herbs have rare side effects because of presence of phenolic compounds and flavonoids which are widely distributed in plants along with antioxidant activities than chemical drugs and their antioxidant features decrease the drugs toxicity. Nowadays herbal drugs are used as a substitute to chemical drugs because of their lower side effects as compared to chemical drugs.

Our findings show similarity with Payamalle et al. (2017) who reported that Garcinia xanthochymus seeds extract shows antioxidant, anti-diabetic and biochemical activities in alloxan induced diabetic rats. High pressure liquid chromatography (HPLC) study ensured the existence of phenolic complexes specially gallic acid, tannic acid and 4-hydroxybenzoic acid which ensure an imperative role as an anti-diabetic action. Tafesse et al. (2017) who reported that Ajuga remotabenth leaves extract shows good antidiabetic activity by reducing blood glucose levels probably because of the occurrence of antioxidant ingredients like flavonoids. It was reported by Ayatollahi et al. (2019) that seed extract of date in alloxan induced diabetic rat's shows anti-hyperglycemic and anti-lipidemic effects so results proved that date seed extract recognized as a harmless and effective candidate in fighting against diabetes. Diabetes mellitus is a syndrome distressing the worldwide public fitness in both developing and underdeveloped states. It was reported by IDF that in 2015, 415 million adolescents are affected by DM and it is expected that this ratio is augmented up to 642 million by 2040 (Payamalle et al. 2017). Now, several man-made drugs have been utilized for the cure of DM. But they have severe side effects including weight gain, drug resistance and dropsy. So, innumerable medicinal peptides/plants have shown impending anti-diabetic outcomes with fewer side effects.

\section{Conclusion}

The current work exposed that $P$. trifoliate seeds peptides extract were scrutinized for antibacterial, antioxidant and antidiabetic activity. The outcomes of the present study revealed that seeds extracted from $P$. trifoliata have significantly bioactive peptides that showed higher potential as an antibacterial, antioxidative and antidiabetic effect. Therefore, $P$. trifoliataseeds extract can be recognized as a harmless and capable for utilized as antibacterial, antidiabetic agent and an imperative source for herbal drugs synthesis and lessen the problem of multiple drug resistance particularly in case of pathogenic bacterial strains.

\section{Acknowledgements}

The authors are highly thankful for providing the animal house facility at Department of Pharmacy, University of Sargohda, Pakistan

\section{Author Contributions}

TM and RWA conceived and planned the experiments. RWA carried out the experiments. TM, FM, SS, HM and SI contributed to the interpretation of the results. TM, FN and SS took the lead in writing the manuscript. All authors provided critical feedback and helped to shape the research, analysis and writing manuscript.

\section{Conflict of Interest}

All authors declare no conflict of interest.

\section{Data Availability}

Data presented in this study will be available on a fair request to the corresponding author

\section{Ethical Approval}

The animals were saved animal house at Department of Pharmacy, University of Sargodha, Pakistan, according to "Principals of Laboratory Animal Care" (NIH publication 85-23, reviewed in 1985). 


\section{References}

Abuin E, E Lissi, P Ortiz, C. Henriquez (2002). Uric acid reaction with DPPH radicals at the micellar interface. Bol Soc Chil Quim 47:145-149

Ali AS, AA Elozeiri (2017). Metabolic processes during seed germination, pp:141-166. Advances in Seed Biology

Ali MB, M Irshad, Z Anwar, M Zafar, M Imran (2016). Screening and statistical optimization of physiochemical parameters for the production of xylanases from agro-industrial wastes. Adv Enz Res 4:20-33

Arruda M, F Silva, A Egito, T Silva, J Lima-Filho, A Porto, K Moreira (2012). New peptides obtained by hydrolysis of caseins from bovine milk by protease extracted from the latex Jacaratia corumbensis. LWT Food Sci Technol 49:73-79

Ayatollahi SA, M Sharifi-Rad, A Roointan, N Baghalpour, B Salehi, ZK Shinwari, AT Khalil, J Sharifi-Rad (2019). Antidiabetic activity of date seed methanolic extracts in alloxan-induced diabetic rats. Pak Vet J 39:583-587

Brand-Williams W, ME Cuvelier, C Berset (1995). Use of a free radical method to evaluate antioxidant activity. LWT Food Sci Technol 28:25-30

Costa IRD, PASD Souza, JRC Bloch, RM Llamoca-Zarate, FA Campos (2001). Isolation and Characterisation of a Reserve Protein from the Seeds of Cereus jamacaru (Cactaceae). Braz J Med Biol Res 44:331-335

Derakhshan Z, M Ferrante, M Tadi, F Ansari, A Heydari, MS Hosseini, GO Conti, EK Sadrabad (2018). Antioxidant activity and total phenolic content of ethanolic extract of pomegranate peels, juice and seeds. Food Chem Toxicol 114:108-111

Fields K, T Falla, K Rodan, L Bush (2009). Bioactive peptides: Signaling the future. J Cosm Derm 8:8-13

Grancieri M, HSD Martino, EGD Mejia (2019). Chia seed (Salvia hispanica L.) as a source of proteins and bioactive peptides with health benefits: A review. Comprehens Rev Food Sci Food Saf 18:480-499

Hall DG, ED Ammar, KD Bowman (2018). Epifluorescence and stereomicroscopy of trichomes associated with resistant and susceptible host plant genotypes of the Asian citrus psyllid (Hemiptera: Liviidae), vector of citrus greening disease bacterium. $J$ Micros Ultra 6:56-63

Health NI (1985). Principles of Laboratory Animal Care. 85-23. NIH Publications, Bethesda, Maryland, USA

Iranloye B, A Arikawe, G Rotimi, A. Sogbade (2011). Anti-diabetic and anti-oxidant effects of Zingiber officinale on alloxan-induced and insulin-resistant diabetic male rats. Nig J Physiol Sci 26:89-96

Kaur J, V Kumar, K Sharma, S Kaur, Y Gat, A Goyal, B Tanwar (2020). Opioid peptides: An overview of functional significance. Intl J Pep Res Ther 26:33-41

Khan BM, J Bakht, M Shafi (2017). Screening of leaves extracts from Calamus aromaticus for their antimicrobial activity by disc diffusion assay. Pak J Pharm Sci 30:793-800
Kooti W, N Daraei (2017). A review of the antioxidant activity of celery (Apiumgraveolens L). J Evid Based Compl Altern Med 22:1029-1034

Kumar K, S Mounika, P Sudhakar, B Sandeep (2016). Evaluation of biochemical and phytochemical parameters in germinating and nongerminating seeds of Cucurbita maxima. Intl J Appl Sci Eng Res 5:341-353

Mazorra-Manzano M, J Ramirez-Suarez, R Yada (2018). Plant proteases for bioactive peptides release: A review. Crit Rev Food Sci Nutr 58:2147-2163

Mehmood T, T Saman, M Asgher, M Irfan, Z Anwar, F Nadeem, A. Siddiqa (2019). Optimization of cultural parameters for pectin methylestrase and polygalacturonase production from Schizophyllum commune in solid state fermentation. Bang J Bot 48:65-74

Minkiewicz P, A Iwaniak, M Darewicz (2019). BIOPEP-UWM database of bioactive peptides: Current opportunities. Intl J Mol Sci 20:59786000

Mohanty D, S Mohapatra, S Misra, P Sahu (2016). Milk derived bioactive peptides and their impact on human health - a review. Saudi J Biol Sci 23:577-583

Moller NP, KE Scholz-Ahrens, N Roos, J Schrezenmeir (2008). Bioactive peptides and proteins from foods: Indication for health effects. Eur $J$ Nutr 47:171-182

Muruganantham N, S Solomon, M Senthamilselvi (2016). Antimicrobial activity of Cucurbita maxima flowers (pumpkin). J Pharmacog Phytochem 5:15-18

Nadeem F, T Mehmood, M Naveed, S Shamas, T Saman, Z Anwar (2019). Protease production from Cheotomium globusum through central composite design using agricultural wastes and its immobilization for industrial exploitation. Waste Biomass Valoriz 11:6529-6539

Naveed M, F Nadeem, T Mehmood, M Bilal, Z Anwar, F Amjad (2020). Protease - a versatile and ecofriendly biocatalyst with multiindustrial applications: An updated review. Catal Lett 151:307-323

Payamalle S, KS Joseph, SC Bijjaragi, C Aware, JP Jadhav, HN Murthy (2017). Anti-diabetic activity of Garcinia xanthochymus seeds. Compar Clin Pathol 26:437-446

Salampessy J, M Phillips, S Seneweera, K Kailasapathy (2010). Release of antimicrobial peptides through bromelain hydrolysis of leatherjacket (Meuchenia spp.) insoluble proteins. Food Chem 120:556-560

Salman MT, RA Khan, I Shukla (2016). Antibacterial activity of Nigella sativa Linn. seeds against multiple antibiotics resistant clinical strains of Staphylococcus aureus. Intl Arch Biomed Clin Res 2:96-99

Tafesse TB, A Hymete, Y Mekonnen, M Tadesse (2017). Antidiabetic activity and phytochemical screening of extracts of the leaves of Ajuga remota Benth on alloxan-induced diabetic mice. BMC Complem Altern Med 17; Article 243

Tundis R, M Bonesi, V Sicari, T Pellicano, M Tenuta, M Leporini, F Menichini, M Loizzo (2016). Poncirus trifoliata (L.) Raf.: Chemical composition, antioxidant properties and hypoglycaemic activity via the inhibition of $\alpha$-amylase and $\alpha$-glucosidase enzymes. $J$ Funct Foods 25:477-485

Walther B, R Sieber (2011). Bioactive proteins and peptides in foods. Intl J Vitam Nutr Res 81:181-192 